\title{
Triple Fundal Coloboma: irregular closure of the embryonic cleft in the optic cup
}

\author{
Ravi Bypareddy, Brijesh Takkar, Shorya Vardhan Azad, Rohan Chawla
}

Dr Rajendra Prasad Centre for Ophthalmic Sciences, All India Institute of Medical Sciences, New Delhi, India

\section{Correspondence to} Dr Shorya Vardhan Azad, shoryaazad@hotmail.com

Accepted 9 September 2016

\section{DESCRIPTION}

A 45-year-old woman on routine evaluation was found to have coloboma of optic nerve head and two inferior choroidal colobomas (CCs) connected by a bridging retinal tissue in the left eye (figure 1A). Vertical optical coherence tomography (OCT) line scan through the CCs revealed thin rudimentary retinal tissue typical of an intercalary membrane along with an absent choroidal tissue and ectatic sclera. Notably, a 'hump' was seen between the CCs corresponding to the bridging tissue (figure 1B). Horizontal scan through the 'hump' showed a poorly developed thin retinal tissue with indecipherable layers and an underlying maldeveloped choroid with patchy presence of choroidal vessels (figure 1C). The fovea was normal. Right eye fundus was normal. Best-corrected visual acuity and anterior segments were normal in both the eyes.

Normal closure of the embryonic cleft in the optic cup occurs inside out and in anterior to posterior direction. ${ }^{1}$ Some authors have stated that the closure begins in the ciliary body area and proceeds both ways along its long axis. ${ }^{1}$ Defective closure can result in CC, optic nerve head coloboma and persistence of fetal vasculature. ${ }^{2}$ The presence of multiple colobomas and partially developed chorioretinal tissue in our case are supportive of the postulated patchy closure of the fissure. ${ }^{2}$ OCT of a normal appearing bridging tissue, revealed partial closure with chorioretinal remnants. Similar OCT features of CC have been seen previously, though the bridging tissue lacked detailed evaluation. ${ }^{3}$

Therefore, OCT imaging of multiple colobomas and the intervening transition zone presents a rare but very good opportunity to better understand closure of the embryonic optic cup cleft.

\section{Learning points}

Defective and interrupted closure of the embryonic cleft in the optic cup may lead to multiple colobomas.

- Optical coherence tomography of the clinically normal looking bridging retina may reveal an incomplete closure as well.

Contributors RB was involved in diagnosis, imaging and review with approval of final draft of manuscript. BT was involved in interpretation of images and review with approval of final draft of manuscript. SVA was involved in interpretation of images, writing and review with final approval of final draft of manuscript. RC contributed to interpretation of images, writing and review with approval of final draft of manuscript. SVA is responsible for the overall content as guarantor.

Competing interests None declared.

Patient consent Obtained.

Provenance and peer review Not commissioned; externally pee reviewed.

\section{REFERENCES}

1 Schubert HD. Structural organization of choroidal colobomas of young and adult patients and mechanism of retinal detachment. Trans Am Ophthalmol Soc 2005;103:457-72.

2 Onwochei BC, Simon JW, Bateman JB, et al. Ocular colobomata. Surv Ophthalmol 2000;45:175-94.

3 Gopal L, Khan B, Jain S, et al. A clinical and optical coherence tomography study of the margins of choroidal colobomas. Ophthalmology 2007;114:571-80.

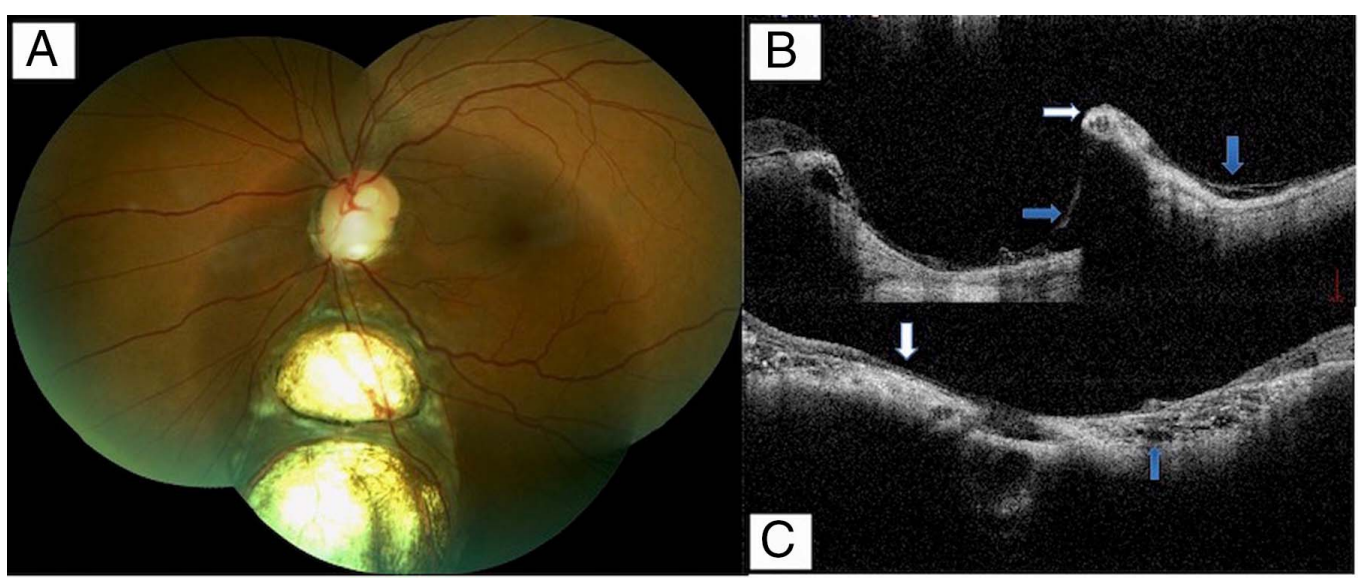

To cite: Bypareddy $R$, Takkar B, Azad SV, et al. BMJ Case Rep Published online: [please include Day Month Year] doi:10.1136/ bcr-2016-216984
Figure 1 (A) Triple fundal coloboma: optic nerve head coloboma with two choroidal colobomas. Characterisitc choroidal atrophy can be seen surrounding the colobomatous area in the optic nerve head. (B) Thin rudimentary retinal layers typical of an intercalary membrane (blue arrow) with hump (white arrow) between the two colobomas. (C) Bridging tissue showing peripheral retinal (white arrow) and choroidal remnants (blue arrow) in a shallow ectatic sclera. 
Copyright 2016 BMJ Publishing Group. All rights reserved. For permission to reuse any of this content visit http://group.bmj.com/group/rights-licensing/permissions.

BMJ Case Report Fellows may re-use this article for personal use and teaching without any further permission.

Become a Fellow of BMJ Case Reports today and you can:

- Submit as many cases as you like

- Enjoy fast sympathetic peer review and rapid publication of accepted articles

- Access all the published articles

- Re-use any of the published material for personal use and teaching without further permission

For information on Institutional Fellowships contact consortiasales@bmjgroup.com

Visit casereports.bmj.com for more articles like this and to become a Fellow 